\title{
Spontaneous Bacterial Peritonitis and Procalcitonin Levels in the Serum and Ascites of Liver Cirrhosis Patients
}

\author{
Toru Shizuma* \\ Department of Physiology, School of Medicine, Tokai University, Japan
}

Received: July 10, 2014; Accepted: September 02, 2014; Published: October 10, 2014

*Corresponding author: Toru Shizuma, Department of Physiology, School of Medicine, Tokai University, Japan, Tel: +81-0463-93-1121; Fax: +81-046393-6684; E-mail: shizuma@is.icc.u-tokai.ac.jp

\begin{abstract}
Patients with Liver Cirrhosis (LC) are at a high risk of developing bacterial infections. Spontaneous Bacterial Peritonitis (SBP) is the most common and sometimes fatal complication in LC patients. Therefore, novel and useful biomarkers for the early diagnosis of SBP are needed. Procalcitonin (PCT) is a biomarker used for the early diagnosis of bacterial infections in LC patients. However, the usefulness of PCT for diagnosing SBP in LC patients is yet unclear. This manuscript reviews data regarding PCT levels in the serum and ascites of patients with LC complicated by SBP.
\end{abstract}

Keywords: Spontaneous bacterial peritonitis; Procalcitonin; Liver cirrhosis; Ascites; Bacterial infection

\section{Introduction}

Patients with Liver Cirrhosis (LC) are at high risk for developing bacterial infections, as LC leads to hypoactive phagocytic cells or opsonic activity in the hepatic reticuloendothelial system and bacterial influx into the general circulation through portacaval shunts [1]. The most common bacterial infection in LC patients is Spontaneous Bacterial Peritonitis (SBP), followed by urinary tract infection, pneumonia, soft tissue infection, and bacteremia [1-5]. In LC patients, the increase in proinflammatory cytokines and hemodynamic derangement associated with bacterial infections leads to serious consequences, including sepsis and multiple organ failure [1]. In bacterial infections such as SBP in LC patients, renal impairment is one of the prognostic factors, and type-1 hepatorenal syndrome is associated with a particularly poor prognosis [6,7]. On the contrary, the prevalence of infections caused by multidrug-resistant bacteria has increased in patients with LC in recent years $[8,9]$. Moreover, a delay in the diagnosis of a bacterial infection is often fatal in LC patients [10]. Therefore, early and accurate diagnosis of bacterial infections is particularly important in LC patients.

Procalcitonin (PCT), a 116-amino acid prohormone of calcitonin, is normally synthesized in the $\mathrm{C}$ cells of the thyroid gland, and the current reference value (cut-off value) is estimated to be approximately $0.5 \mathrm{ng} / \mathrm{mL}$ in healthy populations [11-13]. Moreover, production of PCT occurs in various organs including the liver, lung, and kidneys during other medical conditions
[14]. PCT is a well-known acute phase reactant protein as well as a $\mathrm{C}$ - reactive protein (CRP) [15]. PCT release during infection may be induced directly by microbial toxins and indirectly by humoral factors or a cell-mediated host response [13]. Bacterial endotoxins are the main stimulus for production of PCT and other cytokines such as Tumor Necrosis Factor (TNF)- $\alpha$ and Interleukin (IL)-6, which are involved in initiating acute phase responses in humans [12]. However, in liver insufficiencies such as LC, reduced catabolism of TNF- $\alpha$ and IL- 6 is observed [12]. Therefore, compared with non-LC patients, TNF- $\alpha$ and IL- 6 levels may be estimated to be less sensitive and specific in LC patients with bacterial infection [12]. High PCT levels were estimated to be a sensitive and specific marker for the initial diagnosis of bacterial infections $[12,13,16]$. Elevated serum PCT levels are more accurate indicators of bacterial infections than elevated CRP, TNF- $\alpha$, or IL- 6 levels $[12,17]$, although these findings are controversial [18]. Viral infections, autoimmune disorders, allergic reactions, and local bacterial infections generally do not elevate PCT levels [13]. A recent review report and meta-analysis indicated that PCT is a helpful biomarker for early diagnosis of sepsis in critically ill patients, although it is not recommended for use as a single definitive test for diagnosing sepsis [19].

The value of using PCT levels for diagnosing infections such as SBP in LC patients has not been well established. Here we summarize the present data regarding PCT levels in the serum and ascites of patients with LC complicated by bacterial infections such as SBP.

\section{Possible mechanisms of SBP and bacteremia in LC patients}

The onset of SBP and bacteremia in LC patients occurs due to changes in the composition of the intestinal bacterial flora, breakdown of the intestinal mucosal barrier because of gastrointestinal bleeding, or the translocation of pathological bacterial from the intestine to mesenteric lymph nodes $[20,21]$. Bacterial translocation is reportedly common among patients with LC and severe liver dysfunction [21,22]. Bacteremia develops more frequently among patients who undergo catheterization or endoscopic procedures and in those who experience gastrointestinal bleeding [5]. 


\section{Bacterial infections in LC patients}

Of inpatients with LC, 30\%-60\% develop a bacterial infection $[2,4,5]$. Bacterial infections are involved in approximately $25 \%$ of deaths among LC patients [23]. Recent hospital mortality rates for all SBP cases are reported as 10\%-50\%, with 31\% and 93\% for the first and second/subsequent episodes, respectively [24]. Mortality rates at 1 and 2 years of following an episode of SBP are reported to be $50 \%-70 \%$ and $70 \%-75 \%$, respectively $[2,3]$.

\section{Comparison of PCT levels between LC and non-LC patients}

The liver is a major source of PCT and CRP [14]. Because liver insufficiency leads to decreased catabolism of TNF- $\alpha$ and IL-6, PCT levels might differ between patients with and without liver dysfunction [12]. However, Bota et al. [14] reported that serum PCT levels in LC patients with bacterial infection are not significantly lower than those in non-LC patients with bacterial infection. LC involves cellular and cytokine inflammatory responses and several studies have documented proinflammatory markers in the serum and ascites of LC patients [6] Increasing serum PCT levels (> $0.5 \mathrm{ng} / \mathrm{mL}$ ) are often seen in LC patients without bacterial infections [6].

\section{Serum PCT levels in patients with LC complicated by bacterial infections}

Many studies have indicated that serum PCT levels are significantly higher in LC patients with bacterial infections (excluding SBP) than in those without infections. Serum PCT levels are being considered as a marker for early diagnosis of bacterial infections in LC and non-LC patients [11,12,15,18].

\section{Diagnosis of SBP in LC patients}

SBP is defined as an infection in the ascitic fluid without any apparent intra-abdominal source of infection or malignancy [2]. Therefore, patients with infectious pleural effusion, peritonitis carcinomatosa, or hemorrhagic ascites as seen with hepatocellular carcinoma rupture are excluded from a diagnosis of SBP. Regardless of the presence or absence of bacteria in the ascitic fluid, SBP is diagnosed in cases with an ascitic fluid Polymorphonuclear (PMN) cell count $\geq 250$ cells $/ \mathrm{mm}^{3}[3,24,25]$. Patients with Culture Negative Neutrocytic Ascites (CNNA) with a PMN cell count $\geq 250$ cells $/ \mathrm{mm}^{3}$ are also diagnosed with SBP [3].

Cultures of ascitic fluid are positive in $35 \%-65 \%$ of patients with SBP [20]. However, standard culture techniques fail to grow bacteria in up to $65 \%$ of neutrocytic ascites samples [24]. The positivity of ascites cultures has been reported to increase when the fluid is placed directly into blood culture flasks at the bedside, immediately after collection $[20,24]$. The usefulness of ascites $\mathrm{pH}$, lactate and lactoferrin levels for the diagnosis of SBP has not been confirmed [20]. The possible usefulness of ascites Macrophage Inflammatory Protein type 1 beta (MIP-1 $\beta$ ) levels for diagnosis of SBP was recently reported [26]. However, there is little evidence supporting MIP-1 $\beta$ use as a marker at present $[6,26]$.

\section{PCT levels in patients with LC complicated by SBP}

Ascitic fluid culture examination is time consuming and not always possible [27]. In patients with LC complicated by SBP, TNF- $\alpha$ and IL- 6 levels are significantly higher than those in LC patients with sterile ascites [16]. PCT is a sensitive marker of systemic inflammatory infection such as sepsis. However, there have been conflicting results regarding the use of PCT levels in serum and ascitic fluid as an accurate marker of SBP. This difference may be partially explained by the absence of a systemic inflammatory response in some cases of SBP [12]. However, Connert et al. [12] reported no significant differences in serum PCT levels between LC patients with bacterial infections and those with SBP.

\section{Comparison of serum or ascitic PCT levels between patients with LC and SBP and LC and sterile ascites}

Several studies have compared PCT levels between patients with LC and SBP and those with LC and sterile ascites. Results of these studies (serum PCT levels, 6 studies [16,26-30]; ascitic fluid PCT levels, 3 studies[16,26,28]) are summarized in Tables 1 and 2. Regarding serum (or plasma) PCT levels, 5 out of 6 reports indicated that serum PCT levels were considerably higher in patients with SBP than in those with sterile ascites [16,27-30]. Only one study reported no significant differences in the serum PCT level between patients with SBP and those with sterile ascites [26]. However, this study included only 10 SBP cases; thus, the relevance of its findings is limited. In a meta-analysis of data from 3 studies $[12,16,28]$, Su et al. [17] reported that PCT is a promising marker for predicting SBP and suggested that serum PCT levels are more accurate for diagnosing SBP than serum CRP, serum IL-6, or ascetic fluid PCT levels.

Of the three reports that investigated ascitic fluid PCT levels $[16,26,28]$, two indicated no significant differences in PCT levels between patients with SBP and those with sterile ascites. However, two of these studies included only 10 SBP cases, limiting the relevance of their findings $[26,28]$. The remaining study reported that ascitic fluid PCT levels in SBP were significantly higher than those in sterile ascites but that ascitic fluid PCT levels were less accurate than IL-6 levels for the diagnosis of SBP [16].

Table 1: Comparison of serum procalcitonin levels $(\mathrm{ng} / \mathrm{mL})$ between SBP and sterile ascites in liver cirrhosis patients in reported studies. (SBP: Spontaneous Bacterial Peritonitis, " Median (Range), ${ }^{* *}$ Mean \pm SD (Range)).

\begin{tabular}{|c|c|c|c|}
\hline $\begin{array}{c}\text { Authors } \\
\text { [Reference] }\end{array}$ & $\begin{array}{c}\text { SBP } \\
\text { (n) }\end{array}$ & $\begin{array}{c}\text { Sterile ascites } \\
\text { (n) }\end{array}$ & p-value \\
\hline Viallon et al. [16] & $\begin{array}{c}10.10(2.6-24.0)^{*} \\
(\mathrm{n}=21)\end{array}$ & $\begin{array}{c}0.09(0.0-0.23)^{*} \\
(\mathrm{n}=40)\end{array}$ & 0.0001 \\
\hline Spahr et al. [28] & $\begin{array}{c}0.74 \pm 0.6(0.1- \\
1.72)^{* *} \\
(\mathrm{n}=10)\end{array}$ & $\begin{array}{c}0.2 \pm 0.1(0.14- \\
0.46)^{* *} \\
(\mathrm{n}=10)\end{array}$ & $<0.05$ \\
\hline Cekin et al. [27] & $\begin{array}{c}1.01(0.04-36.4)^{*} \\
(\mathrm{n}=59)\end{array}$ & $\begin{array}{c}0.3(0.1-3.7)^{*} \\
(\mathrm{n}=24)\end{array}$ & $<0.001$ \\
\hline Yuan et al. [29] & $\begin{array}{c}0.62(0.52-0.81)^{*} \\
(\mathrm{n}=42)\end{array}$ & $\begin{array}{c}0.28(0.16-0.46)^{*} \\
(\mathrm{n}=42)\end{array}$ & $<0.0001$ \\
\hline Lesińska et al. & $\begin{array}{c}1.08 \pm 1.34(?-?)^{* *} \\
{[26]}\end{array}$ & $\begin{array}{c}0.44 \pm 0.44(?-?)^{* *} \\
(\mathrm{n}=10)\end{array}$ & 0.51 \\
\hline Wu et al. [30] & $\begin{array}{c}0.73(?-?)^{*} \\
(\mathrm{n}=111 ?)\end{array}$ & $\begin{array}{c}0.15(?-?)^{*} \\
(\mathrm{n}=40 ?)\end{array}$ & $<0.001$ \\
\hline
\end{tabular}


Moreover, several studies have suggested the use of parameters, such as the cutoff value of serum PCT levels, to discriminate between SBP and non-SBP (sterile ascites) in patients with LC and ascites. Results of these six studies $[12,16,26,27,29,30]$ are summarized in Table 3. The usefulness of serum PCT and its parameters [cutoff values, Area Under the Curve (AUC), sensitivity, specificity, Positive Predictive Value (PPV), and Negative Predictive Value (NPV)] used for the diagnosis of SBP were reported as follows. 1) Yuan et al. [29] found that serum PCT (cutoff value, $0.48 \mathrm{ng} / \mathrm{mL}$; AUC, 89\%; sensitivity, 95\%; specificity, 79\%) was a better marker than white blood cell count in peripheral blood for the diagnosis of SBP in patients with HBV-infected LC. 2) Viallon et al. [16] stated that serum PCT (cutoff value, $0.76 \mathrm{ng} / \mathrm{mL}$; AUC, 98\%; sensitivity, 95\%; specificity, 98\%; PPV, 95\%; NPV, 98\%) was a suitable marker for predicting SBP. 3) Cekin et al. [27] indicated that serum PCT (cutoff value, $0.61 \mathrm{ng} / \mathrm{mL}$; AUC, $98.1 \%$; sensitivity, $100 \%$; specificity, $92 \%$ ) was a good marker for predicting SBP and more accurate than serum CRP for diagnosing SBP. 4) Wu et al. [30] stated that serum PCT (cutoff value, $0.462 \mathrm{ng} / \mathrm{mL}$; AUC, 95\%; sensitivity, 83.7\%; specificity, 94.9\%) was a good marker for predicting SBP. 5) Connert et al. [12] reported that serum PCT (cutoff value, $0.615 \mathrm{ng} / \mathrm{mL}$; sensitivity, $94.7 \%$; specificity, $70.4 \%$ )

Table 2: Comparison of ascitic flluid procalcitonin levels (ng/mL) between SBP and sterile ascites in liver cirrhosis patients in reported studies. (SBP: Spontaneous Bacterial Peritonitis, ${ }^{*}$ Median (Range), ${ }^{* *}$ Mean \pm SD (Range)).

\begin{tabular}{|c|c|c|c|}
\hline $\begin{array}{c}\text { Authors } \\
\text { [Reference] }\end{array}$ & $\begin{array}{c}\text { SBP } \\
\text { (n) }\end{array}$ & $\begin{array}{c}\text { Sterile ascites } \\
\text { (n) }\end{array}$ & p-value \\
\hline $\begin{array}{c}\text { Viallon et al. } \\
{[16]}\end{array}$ & $\begin{array}{c}1.30(0.7-2.5)^{*} \\
(\mathrm{n}=21)\end{array}$ & $\begin{array}{c}0.08(0.0-0.20)^{*} \\
(\mathrm{n}=40)\end{array}$ & 0.0001 \\
\hline $\begin{array}{c}\text { Spahr et al. } \\
{[28]}\end{array}$ & $\begin{array}{c}0.56 \pm 0.6(0.11-2)^{* *} \\
(\mathrm{n}=10)\end{array}$ & $\begin{array}{c}0.18 \pm 0.1(0.12- \\
0.39)^{* *} \\
(\mathrm{n}=10)\end{array}$ & $\geq 0.05$ \\
\hline $\begin{array}{c}\text { Lesińska et al. } \\
{[26]}\end{array}$ & $\begin{array}{c}1.30 \pm 2.60(?-?)^{* *} \\
(\mathrm{n}=10)\end{array}$ & $\begin{array}{c}0.38 \pm 0.38(?-?)^{* *} \\
(\mathrm{n}=22)\end{array}$ & 0.48 \\
\hline
\end{tabular}

Table 3: Parameters of serum procalcitonin levels $(\mathrm{ng} / \mathrm{mL})$ in patients with liver cirrhosis and spontaneous bacterial peritonitis as reported in six studies (AUC: Area Under the Curve; PPV: Positive Predictive Value; NPV: Negative Predictive Value).

\begin{tabular}{|c|c|c|c|c|c|c|}
\hline $\begin{array}{c}\text { Authors } \\
\text { [Reference] }\end{array}$ & $\begin{array}{c}\text { AUC } \\
\text { (\%) }\end{array}$ & $\begin{array}{c}\text { Cutoff value } \\
\text { (ng/mL) }\end{array}$ & $\begin{array}{c}\text { Sensitivity } \\
\text { (\%) }\end{array}$ & $\begin{array}{c}\text { Specificity } \\
\text { (\%) }\end{array}$ & $\begin{array}{c}\text { PPV } \\
\text { (\%) }\end{array}$ & $\begin{array}{c}\text { NPV } \\
\text { (\%) }\end{array}$ \\
\hline $\begin{array}{c}\text { Viallon et al. } \\
{[16]}\end{array}$ & 98 & 0.76 & 95 & 98 & 95 & 98 \\
\hline $\begin{array}{c}\text { Connert et } \\
\text { al. } \\
{[12]}\end{array}$ & $?$ & 0.615 & 94.7 & 70.4 & $?$ & $?$ \\
\hline $\begin{array}{c}\text { Cekin et al. } \\
{[27]}\end{array}$ & 98.1 & 0.61 & 100 & 92 & $?$ & $?$ \\
\hline $\begin{array}{c}\text { Yuan et al. } \\
{[29]}\end{array}$ & 89 & 0.48 & 95 & 79 & $?$ & $?$ \\
\hline $\begin{array}{c}\text { Lesińska et } \\
\text { al. [26] }\end{array}$ & 58 & $?$ & 30 & $?$ & $?$ & $?$ \\
\hline $\begin{array}{c}\text { Wu et al. } \\
{[30]}\end{array}$ & 95 & 0.462 & 83.7 & 94.9 & $?$ & $?$ \\
\hline
\end{tabular}

Table 4: Parameters of ascitic procalcitonin levels $(\mathrm{ng} / \mathrm{mL})$ in patients with liver cirrhosis and spontaneous bacterial peritonitis as reported in 2 studies (AUC: Area Under the Curve; PPV: Positive Predictive Value; NPV: Negative Predictive Value).

\begin{tabular}{|c|c|c|c|c|c|c|}
\hline $\begin{array}{c}\text { Authors } \\
\text { [Reference] }\end{array}$ & $\begin{array}{c}\text { AUC } \\
(\%)\end{array}$ & $\begin{array}{c}\text { Cutoff } \\
\text { value } \\
\text { (ng/mL) }\end{array}$ & $\begin{array}{c}\text { Sensitiv- } \\
\text { ity } \\
(\%)\end{array}$ & $\begin{array}{c}\text { Specific- } \\
\text { ity } \\
(\%)\end{array}$ & $\begin{array}{c}\text { PPV } \\
(\%)\end{array}$ & $\begin{array}{c}\text { NPV } \\
(\%)\end{array}$ \\
\hline $\begin{array}{c}\text { Viallon et al. } \\
{[16]}\end{array}$ & 96 & 0.30 & 95 & 85 & 77 & 97 \\
\hline $\begin{array}{c}\text { Lesińska et } \\
\text { al. [26] }\end{array}$ & 58 & $?$ & 20 & $?$ & $?$ & $?$ \\
\hline
\end{tabular}

was a good marker for predicting SBP. However, Lesińska et al. [26] reported that serum PCT level (AUC, 58\%; sensitivity, 30\%) is not a good marker for predicting SBP.

Two studies suggested the use of these parameters for the diagnosis of SBP based on the ascitic fluid PCT levels of patients with LC $[16,26]$. The results of these two studies are summarized in Table 4. Viallon et al. [16] reported that ascetic fluid PCT level (cutoff value, $0.30 \mathrm{ng} / \mathrm{mL}$; AUC, 96\%; sensitivity, 95\%; specificity, 85\%; PPV, 77\%; NPV, 97\%) was a suitable marker for predicting SBP. However, Lesińska et al. [26] reported that the ascetic fluid PCT level (AUC 58\%; sensitivity 20\%) was not an adequate marker for the diagnosis of SBP.

\section{PCT levels in other liver diseases}

Oruc et al. [15] reported that serum PCT levels were within normal ranges in both steatohepatitis and steatosis patients, although serum CRP levels were reported to be elevated in steatohepatitis patients and in severely obese patients with diabetes [8]. Elefsinoitis et al. [9] reported that serum PCT levels in chronic hepatitis $\mathrm{C}$ patients under INF- $\alpha$ plus Ribavirin treatment remained within normal limits $(<0.5 \mathrm{ng} / \mathrm{mL})$, although serum PCT levels slightly declined within the normal range in sustained virological responders. Elefsiniotis et al. [31] also reported that acute alcoholic hepatitis with a cirrhotic background as well as acute viral hepatitis with chronic liver disease without proved bacterial infection induces mild elevation of serum PCT levels ( $>0.5 \mathrm{ng} / \mathrm{mL}$ ). However, the mechanism underlying this observation is unclear.

\section{Conclusion}

Our review of the literature regarding PCT levels in the serum and ascitic fluid of patients with LC complicated by SBP suggests that serum PCT is a sensitive marker for diagnosing SBP; cutoff values of $0.46-0.76 \mathrm{ng} / \mathrm{mL}$ are suggested for differentiating between SBP and sterile ascites. However, the usefulness of the ascitic fluid PCT level for differentiating between SBP and sterile ascites is still uncertain because of the small number of studies conducted. There is no evidence that serum PCT is a good marker for distinguishing SBP from other bacterial infections in LC patients. However, because examination of ascites is essential for diagnosing SBP, serum PCT ( $>0.76 \mathrm{ng} / \mathrm{mL}$ ) may be a useful marker for early diagnosis of SBP before paracentesis. 


\section{References}

1. Bunchorntavakul C, Chavalitdhamrong D. Bacterial infections other than spontaneous bacterial peritonitis in cirrhosis. World J Hepatol. 2012; 4(5): 158-168. doi: 10.4254/wjh.v4.i5.158.

2. Fernández J, Gustot T. Management of bacterial infections in cirrhosis. J Hepatol. 2012; 56(Suppl 1): S1-S12. doi: 10.1016/S01688278(12)60002-6.

3. Desai AP, Reau N, Reddy KG, Te HS, Mohanty S, Satoskar R, et al. Persistent spontaneous bacterial peritonitis: a common complication in patients with spontaneous bacterial peritonitis and a high score in the model for end-stage liver disease. Therap Adv Gastroenterol 2012; 5(5): 275-283. doi: 10.1177/1756283X11417037.

4. Bonnel AR, Bunchorntavakul C, Reddy KR. Immune dysfunction and infections in patients with cirrhosis. Clin Gastroenterol Hepatol. 2011; 9(9): 727-738. doi: 10.1016/j.cgh.2011.02.031.

5. Preda CM, Ghita R, Ghita C, Mindru C, Vlaicu L, Andrei A, et al. A retrospective study of bacterial infections in cirrhosis Maedica (Buchar). 2011; 6(3): 185-192.

6. Attar BM, Moore CM, George M, Ion-Nedelcu N, Turbay R, Zachariah A, et al. Procalcitonin, and cytokines document a dynamic inflammatory state in non-infected cirrhotic patients with ascites. World J Gastroenterol. 2014; 20(9): 2374-2382. doi: 10.3748/wjg.v20. i9.2374.

7. Barbano B, Sardo L, Gigante A, Gasperini ML, Liberatori M, Giraldi GD, et al. Pathophysiology, diagnosis and clinical management of hepatorenal syndrome: from classic to new drugs. Curr Vasc Pharmacol. 2014; 12(1): 125-135.

8. Anty R, Bekri S, Luciani N, Saint-Paul MC, Dahman M, Iannelli A, et al. The inflammatory C-reactive protein is increasesd in both liver and adipose tissue in severely obese patients independently from metabolic syndrome, Type 2 diabetes, and NASH. Am J Gastroenterol. 2006; 101(8):1824-1833.

9. Elefsiniotis IS, Petrocheilou A, Scarmeas N, Ketikoglou I, Pantazis KD, Toutouza M, et al. Serum procalcitonin levels in chronic hepatitis C patients under pegylated interferon-alpha plus ribavirin treatment. J Clin Virol. 2006; 37(4): 329-331.

10. Kang CI, Song JH, Chung DR, Peck KR, Yeom JS, Ki HK, et al. Liver cirrhosis as a risk factor for mortality in a national cohort of patients with bacteremia. J Infect. 2011; 63(5): 336-343. doi: 10.1016/j. jinf.2011.07.012.

11. Li CH, Yang RB, Pang JH, Chang SS, Lin CC, Chen CH, et al. Procalcitonin as a biomarker for bacterial infections in patients with liver cirrhosis in the emergency department. Acad Emerg Med. 2011; 18(2): 121126.

12. Connert S, Stremmel W, Elsing C. Procalcitonin is a valid marker of infection in decompensated cirrhosis. Z Gastroenterol. 2003; 41(2): 165-170.

13. Bode-jänisch S, Schütz S, Schmidt A, Tschernig T, Debertin AS, Fieguth $A$, et al. Serum procalcitonin levels in the postmortem diagnosis of sepsis. Forensic Sci Int. 2013; 226(1-3): 266-272. doi: 10.1016/j. forsciint.2013.01.041.

14. Bota DP, Van Nuffelen M, Zakariah AN, Vincent JL. Serum levels of C-reactive protein and procalcitonin in critically ill patients with cirrhosis of the liver. J Lab Clin Med. 2005; 146(6): 347-351.

15. Oruc N, Ozutemiz O, Yuce G, Akarca US, Ersoz G, Gunsar F, et al. Serum procalcitonin and CRP levels in non-alcoholic fatty liver disease: a case control study. BMC Gastroenterol. 2009; 9:16. doi: 10.1186/1471-
230X-9-16.

16. Viallon A, Zeni F, Pouzet V, Lambert C, Quenet S, Aubert G, et al. Serum and ascitic procalcitonin levels in cirrhotic patients with spontaneous bacterial peritonitis: diagnostic value and relationship to proinflammatory cytokines. Intensive Care Med. 2000; 26(8):1082-1088.

17.Su DH, Zhuo C, Liao K, Cheng WB, Cheng H, Zhao XF. Value of serum procalcitonin levels in predicting spontaneous bacterial peritonitis. Hepatogastroenterology. 2013; 60(124): 641-646.

18. Papp M, Vitalis Z, Altorjay I, Tornai I, Udvardy M, Harsfalvi J, et al. Acute phase proteins in the diagnosis and prediction of cirrhosis associated bacterial infections. Liver Int. 2012; 32(4): 603-611. doi: 10.1111/j.1478-3231.2011.02689.x.

19. Wacker C, Prkno A, Brunkhorst FM, Schlattmann P. Procalcitonin as a diagnostic marker for sepsis: a systematic review and metaanalysis. Lancet infect Dis. 2013; 13(5):426-435. doi: 10.1016/S14733099(12)70323-7.

20.Strauss E. The impact of bacterial infections on survival of patients with decompensated cirrhosis. Ann Hepatol. 2013; 13(1): 7-19.

21. Bellot P, Francés R, Such J. Bacterial translocation in cirrhosis. Gastroenterol Hepatol. 2008; 31(8): 508-514.

22. Thalheimer U, Triantos CK, Samonakis DN, Patch D, Burroughs AK Infection, coagulation, and variceal bleeding in cirrhosis. Gut. 2005; 54(4): 556-563.

23. Cheruvattath $\mathrm{R}$, Balan V. Infections in patients with end-stage liver disease. J Clin Gastroenterol. 2007; 41(4): 403-411.

24. Wiest R, Krag A, Gerbes A. Spontaneous bacterial peritonitis: recent guidelines and beyond. Gut. 2012; 61(2): 297-310. doi: 10.1136/ gutjnl-2011-300779.

25. European Association for the Study of the Liver. EASL clinical practice guidelines on the management of ascites, spontaneous bacterial peritonitis, and hepatorenal syndrome in cirrhosis. J Hepatol. 2010; 53(3): 397-417. doi: 10.1016/j.jhep.2010.05.004.

26. Lesińska M, Hartleb M, Gutkowski K, Nowakowska-Duława E Procalcitonin and macrophage inflammatory protein-1 beta (MIP$1 \beta$ ) in serum and peritoneal fluid of patients with decompensated cirrhosis and spontaneous bacterial peritonitis. Adv Med Sci. 2014; 59(1): 52-56. doi: 10.1016/j.advms.2013.07.006.

27. Cekin Y, Cekin AH, Duman A, Yilmaz U, Yesil B, Yolcular BO. The role of serum procalcitonin levels in predicting ascitic fluid infection in hospitalized cirrhotic and non-cirrhotic patients. Int J Med Sci. 2013; 10(10): 1367-1374. doi: 10.7150/ijms.6014.

28. Spahr L, Morard I, Hadengue A, Vadas L, Pugin J. Procalcitonin is not an accurate marker of spontaneous bacterial peritonitis in patients with cirrhosis. Hepatogastroenterology. 2001; 48(38): 502-505.

29. Yuan LY, Ke ZQ, Wang M, Li Y. Procalcitonin and C-reactive protein in the diagnosis and prediction of spontaneous bacterial peritonitis associated with chronic severe hepatitis B. Ann Lab Med. 2013; 33(6): 449-454. doi: 10.3343/alm.2013.33.6.449.

30.Wu J, Jiang F, Zeng T, Xu H, Lei Y, Zhong S, et al. Role of serum procalcitonin assay for diagnosis of spontaneous bacterial peritonitis in ende-stage liver diseases. Zhongguo Yi Xue Ke Xue Yuan Xue Bao. 2014; 36(1): 37-41. doi: 10.3881/j.issn.1000-503X.2014.01.007.

31. Elefsiniotis IS, Skounakis M, Vezali E, Pantazis KD, Petrocheilou A, Pirounaki $\mathrm{M}$, et al. Clinical significance of serum procalcitonin levels in patients with acute or chronic liver disease. Eur J Gastroenterol Hepatol. 2006; 18(5): 525-530. 